\title{
Penegakan Hukum Terhadap Pelaku Tindak Pidana Penodaan Agama Melalui Ornamen-Ornamen Simbol Keagamaan di Ruang Publik Pada Wilayah Hukum Kota Jambi
}

\author{
Erna Nengsih"), Abdul Bari Azed ${ }^{2)}$, Suzanalisa ${ }^{2)}$ \\ 1)Sekolah Polisi Negara, POLDA Jambi \\ ${ }^{2)}$ Magister Hukum, Universitas Batanghari Jambi \\ ${ }^{1)}$ Pd. Meja, Mestong, Kabupaten Muaro Jambi, Jambi 36361 \\ ${ }^{2)}$ Jl. Slamet Riyadi, Broni, Jambi- Indonesia Tel / Faks: 0741-667084 \\ Correspondence email: ernanengsih719@gmail.com, abdul.bari.azed@unbari.ac.id, suzanalisa@unbari.ac.id
}

\begin{abstract}
Abstrak. Penghinaan atau penodaan terhadap suatu agama yang diakui di Indonesia sering terjadi namun penodaan agama melalui ornament=ornament symbol agama di ruang public pada wilayah Kota Jambi menimbulkan keributan umat Islam dan viral di Indonesia pada tahun 2016. Hal ini tentunya sangat mengganggu kehidupan beragama dan sangat membahayakan kedamaian hidup bermasyarakat dan kesatuan bangsa. Dengan adanya kepentingan hukum yang harus dilindungi tersebut maka sudah sewajarryalah jika pemerintah memiliki kewajiban untuk mengatur kehidupan beragama di Indonesia melalui penerbitan peraturan perundang-undangan yang khusus mengatur tentang kehidupan. Kajian ini menjelaskan tentang kendala-kendala di dalam penegakan hukum tindak pidana penodaan agama melalui ornamenornamen simbol keagamaan dan kebijakan yang dilakukan oleh POLDA Jambi dalam mengatasi kendala-kendala yang ditemui dalam penegakan hukum tindak pidana penodaan agama melalui ornamen-ornamen simbol keagamaan
\end{abstract}

Kata Kunci : Penegakan Hukum, Penodaan Agama melalui Ornamen-ornamen simbol keagamaan

\begin{abstract}
Humiliation or blasphemy against a recognized religion in Indonesia often occurs but blasphemy through religious symbol ornaments in public spaces in the Jambi City area caused a commotion for Muslims and went viral in Indonesia in 2016. This is of course very disturbing religious life and very dangerous. peaceful social life and national unity. With the legal interests that must be protected, it is only natural that the government has an obligation to regulate religious life in Indonesia through the issuance of laws and regulations that specifically regulate life. This study describes the obstacles in law enforcement of the criminal act of blasphemy through the ornaments of religious symbols and the policies carried out by the Jambi Regional Police in overcoming the obstacles encountered in law enforcement of the criminal act of blasphemy through the ornaments of religious symbols.
\end{abstract}

Keywords: Law Enforcement, Blasphemy of Religion through Ornaments of Religious Symbols

\section{PENDAHULUAN}

Perbuatan mengubah, menambah, atau menghilangkan ajaran agama yang sudah ada dianut di Indonesia, bukanlah suatu hak asasi manusia yang harus dihormati dan dilindungi, karena itu adalah perbuatan menista suatu agama atau penodaan agama dapat merusak nilai-nilai kebhinekaan tunggal ika yang menjadi dasar Negara Republik Indonesia sebagai bangsa majemuk yang terdiri dari aneka ragam suku, bahasa, budaya, adat istiadat, dan agama. Salah satu bentuk keanekaragaman yang ada di Indonesia adalah adanya lebih dari satu agama yang dianut warga negara di Indonesia. Jaminan akan kebebasan beragama sebagai hak asasi manusia dijamin oleh konstitusi UUD 1945 dalam Pasal 28E ayat (1) dan ayat (2)

Untuk itu pemerintah, aparatur negara, dan pejabat publik lainnya mempunyai kewajiban dan tanggung jawab menjamin terselenggaranya penghormatan, perlindungan, dan penegakan hak asasi manusia, sebagaimana ditegaskan dalam ketentuan Pasal 8 Undang-Undang Nomor 39 Tahun 1999 yang menegaskan bahwa "Perlindungan, pemajuan, penegakan, dan pemenuhan hak asasi manusia menjadi tanggung jawab negara, terutama pemerintah".

Berdasarkan uraian tersebut di atas, bahwa unsur agama dalam kehidupan hukum Indonesia merupakan faktor yang fundamental, maka dapatlah dimengerti apabila agama dijadikan landasan yang kokoh dan kuat dihidupkan dalam delik-delik agama. Pengaturan tentang tindak pidana penodaan agama dan kehidupan beragama menurut Muladi merupakan refleksi bahwa Indonesia merupakan "Nation State yang religius, di mana semua agama (religion) yang diakui sah di Indonesia merupakan kepentingan hukum yang besar yang 
Erna Nengsih, Abdul Bari Azed, dan Suzanalisa. Penegakan Hukum Terhadap Pelaku Tindak Pidana Penodaan Agama Melalui Ornamen-Ornamen Simbol Keagamaan di Ruang Publik Pada Wilayah Hukum Kota Jambi

harus dilindungi dan tidak sekedar merupakan bagian dari ketertiban umum yang mengatur tentang rasa keagamaan atau ketenteraman hidup beragama. ${ }^{1}$

Tindak pidana terhadap kepentingan agama sering disebut dengan penodaan agama. Aspek mengenai tindak pidana terhadap kepentingan agama tersebut diatur dalam KUHP dengan tujuan melindungi kepentingan agama. Di Dalam KUHP ada tiga kepentingan yang dilindungi yaitu kepentingan individu, kepentingan masyarakat dan kepentingan negara yang masing-masing diperinci ke dalam sub jenis kepentingan lagi. ${ }^{2}$

Penghinaan atau penodaan terhadap suatu agama yang diakui di Indonesia dan ataupun dengan cara lain mengganggu kehidupan beragama akan membahayakan kedamaian hidup bermasyarakat dan kesatuan bangsa. ${ }^{3}$ Dengan adanya kepentingan hukum yang harus dilindungi tersebut maka sudah sewajarryalah jika pemerintah memiliki kewajiban untuk mengatur kehidupan beragama di Indonesia melalui penerbitan peraturan perundangundangan yang khusus mengatur tentang kehidupan beragama di Indonesia. Atas dasar hal tersebut, pemerintah telah menerbitkan Undang-Undang Nomor 1/PNPS/1965 tentang Pencegahan Penyalahgunaan dan/atau Penodaan Agama.

Penodaan agama yang terjadi pada ruang publik pada wilayah hukum Kepolisian Daerah Jambi menggunakan ornamen-ornamen symbol keagamaan yang dilakukan Hal ini bermula tanggal 23 Desember 2016 sekitar pukul 18.30 WIB di ruang lobi dalam Novita Hotel Jalan Gatot Subroto. Pelaku RH melakukan tindakan perubahan ornamen-ornamen natal yang diletakkan di lobby hotel berupa miniatur gereja yang bagian halaman bawah depan terdapat ornament berbentuk sandal jepit ditengahnya terdapat tulisan lafaz allah

Alat yang Tersangka gunakan untuk membuat lafaz Allah sehingga menoda terhadap agama adalah : kedua tangan Tersangka, mob, lobby daster, penggaris, sarung tangan praktikum, kain, kanebo, batu kerikil Tersangka membuat lafaz Allah didalam ornamen natal tersebut sendirian tanpa dibantu oleh orang lain, lafaz Allah yang Tersangka buat didalam ornamen natal tersebut.

Perbuatan pelaku memancing kemarahan Umat Islam merasa terhina dan ternodai agamanya sehingga menjadi viral dimana kasus ini menjadi berita nasional saat itu. Akibatnya Bangsa Indonesia yang menerapkan toleransi beragama menjadi diusik oleh perbuatan pelaku.

Institusi kepolisian didalam pemeliharaan keamanan dan ketertiban masyarakat, penegakan hukum, perlindungan, pengayoman dan pelayanan kepada masyarakat terikat kepada aturan-aturan hukum dan prosedur - prosedur tertentu, serta dikontrol dan bertanggung jawab kepada hukum. Adapun Fungsi dan tugas Kepolisian Negara Republik Indonesia telah diatur di dalam beberapa ketentuan peraturan perundangundangan. Undang-Undang Nomor 2 Tahun 2002 tentang Kepolisian Negara Republik memperluas fungsi dan tugas kepolisian yang meliputi dengan menjunjung tinggi Hak Asasi Manusia (HAM). Dalam Pasal 30 ayat (4) UUD1945 hasil amandemen.

Sebagaimana didalam Hukum pidana memuat ketentuan mengenai perbuatan yang dilarang sebagai tindak pidana, masalah pertanggungjawaban serta ancaman sanksinya yang dapat terwujud dalam berbagai peraturan perundangan hukum pidana. Secara lengkap, Pasal 156 a KUHP berbunyi, "Dihukum dengan hukuman penjara selama-lamanya lima tahun barang siapa dengan sengaja di depan umum mengeluarkan perasaan atau melakukan perbuatan (a) yang pada pokoknya bersifat bermusuhan, penyalahgunaan, atau penodaan terhadap suatu agama yang dianut di Indonesia, (b) dengan maksud supaya orang tidak menganut agama apa pun juga yang bersendikan Ketuhanan Yang Maha Esa.

Perbuatan yang dapat dihukum menurut pasal ini adalah tindakan memusuhi suatu agama yang dianut, menyalahgunakan ajaran agama yang tidak sesuai dengan ajaran agama tersebut dan penodaan terhadap suatu agama, serta mengajak orang mengatur secara tegas perbuatan penghinaan terhadap Tuhan, Nabi, dan kitab suci.

\section{PEMBAHASAN}

A. Kendala-Kendala Yang Dihadapi Dalam Penegakan Hukum Terhadap Pelaku Tindak Pidana Penodaan Agama Melalui Ornamen-Ornamen Simbol Keagamaan Di Ruang Publik Pada Wilayah Hukum Kota Jambi

Tindak Pidana Penodaan Agama Melalui Ornamen-Ornamen Simbol Keagamaan Di Ruang Publik Kota Jambi diatur di dalam Pasal 156 (a) huruf (a) Jo Pasal 64 Ayat (1) sebagai landasan dan pedoman untuk menangkap setiap bentuk tindak pidana penodaan agama. Pasal inilah yang digunakan sebagai dasar bagi pihak Kepolisian untuk melakukan penyidikan terhadap pelaku tindak pidana penodaan

\footnotetext{
${ }^{1}$ Muladi, Beberapa Catatan Berkaitan Dengan RUU KUHP Baru, Makalah Disampaikan pada Seminar Nasional RUU KUHP Nasional Diselenggarakan oleh Universitas Internasional Batam, Batam 17 Januari 2004, hal. 7

${ }^{2}$ Wirjono Prodjodikoro, Asas-Asas hukum Pidana Indonesia, Eresco, Bandung, 1986, hal. 6.

${ }^{3}$ Marzuki Wahid dan Rumadi, Fiqh Madzab Negara, Kritik Atas Politik Hukum Islam Di Indonesia, LKiS, Yogyakarta, 2001, hal. 23.
} 
agama. Sedangkan bagi pihak Kejaksaan, pasal ini digunakan sebagai dasar dan pedoman untuk melakukan penuntutan.

Penuntutan merupakan salah satu tahap di dalam prosedur pemeriksaan perkara pidana yang telah diatur di dalam Undang-Undang No 8 Tahun 1981 tentang Kitab Undang-Undang Hukum Acara Pidana (KUHAP). Prosedur pemeriksaan perkara pidana dipisahkan dalam 4 tingkat acara pidana, yaitu :

1. Tahap penyidikan yang dilakukan oleh Kepolisian Republik Indonesia;

2. Tahap penuntutan yang dilakukan oleh Jaksa Penuntut Umum;

3. Tahap pemeriksaan di sidang pengadilan yang dipimpin oleh Hakim;

4. Tahap pelaksanaan putusan pengadilan yang dijalankan oleh Jaksa dan Lembaga Pemasyarakatan dengan pengawasan/ pengamatan Ketua Pengadilan.

Dalam tahap pemeriksaan di sidang Pengadilan yang dipimpin oleh Hakim, pengajuan tuntutan merupakan salah satu bagian yang ada pada tahap tersebut, pengajuan tuntutan diatur dalam Pasal 182 ayat 1 huruf (a) KUHAP, yang menyebutkan bahwa setelah pemeriksaan dinyatakan selesai, Penuntut Umum mengajukan tuntutan pidana.

Pengajuan tuntutan ini didasarkan pada perangkaian fakta-fakta yang terungkap dalam persidangan menjadi suatu konstruksi peristiwa yang sebenarnya dan terhadap peristiwa itu dianalisis hukumnya baik oleh Jaksa Penuntut Umum, Penasehat Hukum maupun Hakim menurut sudut pandangnya masing-masing. Oleh Jaksa Penuntut Umum analisa ini dimasukkan dalam sebuah surat yang dinamakan surat tuntutan (requisitoir).

Di dalam surat tuntutan itu, antara lain dicantumkan pertimbangan dalam mengajukan tuntutan pidananya yang terdiri dari hal-hal yang memberatkan dan hal-hal yang meringankan terdakwa. Sedangkan pada bagian akhir dari surat tuntutan itu Jaksa Penuntut Umum akan menyebutkan tuntutan pidana atas diri terdakwa.

Di dalam hukum pidana materiil ada batas maksimum khusus ancaman pidana yang tercantum dalam tiap-tiap rumusan tindak pidana, serta batas minimum umum ancaman pidananya mengacu pada Pasal 12 ayat (2) KUHP, yakni 1 (satu) hari. Sehingga dalam mengajukan tuntutan pidana, penuntutan itu berkisar pada batas maksimum khusus dan batas minimum umum ancaman pidana ini, kecuali ada ketentuan pidana yang mengatur secara khusus mengenai batas minimum khusus ancaman pidana.

Dari sisi lain, hal ini menyebabkan terjadinya perbedaan dalam hal pengajuan tunt utan pidana antara perkara pidana yang satu dengan perkara pidana yang lain, tidak terkecuali pada perkara tindak pidana penodaan agama. Dalam kenyataannya pada perkara-perkara penodaan agama dapat terjadi pengajuan tuntutan pidana yang berbeda, walaupun dari sisi kualitasnya perkara-perkara tersebut tidak terlalu berbeda.

Pengajuan tuntuan pidana yang berbeda akan membawa implikasi pula bagi Hakim di dalam menjatuhkan pidana. Implikasi tersebut adalah terjadinya perbedaan dalam hal penjatuhan pidana antara perkara penodaan agama yang satu dengan perkara penodaan agama yang lain, walaupun dari sisi kualitas diantara perkara-perkara penodaan agama tersebut tidak terlalu berbeda. Hal ini antara lain disebabkan karena di dalam penjatuhan putusan pidana itu, Hakim mendasarkan pula pada berat ringannya tuntutan pidana pada terdakwa kasus penodaan agama.

Mengkaji mengenai dasar pertimbangan yang digunakan oleh Jaksa Penuntut Umum dalam menentukan berat ringannya tuntutan pidana terhadap terdakwa kasus penodaan agama, merupakan suatu hal yang perlu dilakukan terlebih-lebih hal ini terkait dengan penjatuhan pidana yang dijatuhkan oleh Hakim terhadap terdakwa kasus penodaan agama tersebut.

Biarpun para pelaku Penodaan agama sudah banyak yang tertangkap dan diputus oleh Hakim, namun tetap saja belum mampu untuk mencegah dan menanggulangi tindak pidana penodaan agama. Dari hasil wawancara penulis, dalam mencegah dan menanggulangi tindak pidana penodaan agama aparat penegak hukum masih banyak mengalami kendala-kendala.

Selanjutnya dalam persidangan di Pengadilan Negeri Jambi mengatakan bahwa kendala dalam menanggulangi penodaan agama ini adalah:

a). Kurangnya pemahaman terdakwa terhadap perbuatan yang dilakukan merupakan penodaan agama

Ditemui dalam persidangan bahwa terdakwa dipengaruhi oleh tingkat pendidikan, pemahaman terhadap agama dan toleransi beragama tidak memahami bahwa perbuatan tersebut merupakan penodaan agama, menimbulkan keresahan, keamanan dan budaya toleransi yang telah berakar sehingga Indonesia memberikan kebebasan beragama di Indonesia yang berakibat di dalam persidangan terdakwa berbelit-belit dalam memberikan keterangan dan tidak mengakui maupun menyesali perbuatannya 
Uraian diatas diperjelas oleh Pelaku RH bahwa perbuatan yang dilakukan sebagai wujud menyatakan pendapat terhadap ketidak adilan yang diberikan oleh Pihak Hotel Novita Jambi agar perbuatan yang dilakukan dapat dilihat oleh umum atau masyarakat banyak juga dilihat oleh pihak management hotel novita dan agar dilihat oleh wartawan sehingga diliput ke media sosial, elektronik, dan media massa sehingga masyarakat umum mengetahui permasalahan dan keburukan management hotel novita jambi dengan tujuan agar seluruh masyarakat mengetahui keburukan management hotel novita jambi, dan pihak management hotel dapat memenuhi semua keinginan seluruh karyawan, memperjuangkan hak-hak karyawan karena sudah terzolimi oleh managenment, sehingga memperhatikan dan mensejahterahkan karyawannya karena gaji selalu telat setiap bulannya, uang service telat, semua karyawan selalu mengeluhkan atas keterlambatan gaji

.b). Sulitnya dan membutuhkan ketelitian dalam memperoleh barang bukti.

Aparat penegak hukum tidak bisa begitu saja menangkap orang yang dicurigai telah melakukan penodaan agama, karena harus mempunyai bukti-bukti yang cukup untuk menangkapnya dan pemahaman tentang kategori tindak pidana penodaan agama dan modus yang dilakukan oleh terdakwa

c). Kurangnya pemahaman masyarakat .

Salah satu pemicu yang dapat menghambat kerja aparat Kepolisian dalam menangkap penodaan agama adalah kurangnya kepedulian dan kesadaran masyarakat untuk mengungkap penodaan agama. Pada hal dibutuhkan kerjasama yang baik antara petugas dengan masyarakat untuk mengungkap penodaan agama Masyarakat harus peka dan aktif terhadap keadaan sekitarnya jika disinyalir ada penodaan agama. Ironisnya kadang-kadang masyarakat disatu sisi resah akan keberadaan penodaan agama, namun disisi lain masyarakat justeru tidak memahami yang dimaksud penodaan agama khususnya pemanfaatan ornament-ornament ketauhidan agama.

\section{B. Kebijakan Yang Dilakukan Dalam Mengatasi Kendala Yang Dihadapi Oleh Kepolisian Daerah Jambi Terhadap Pelaku Tindak Pidana Penodaan Agama Melalui Ornamen-Ornamen Simbol Keagamaan Di Ruang Public Di Wilayah Hukumnya}

Polri sebagai alat penegak hukum berdasarkan undang undang no. 2 tahun 2002 tentang Kepolisian Negara Republik Indonesia menyatakan bahwa tugas Polri adalah memelihara keamanan dan ketertiban masyarakat, menegakkan hukum, dan memberikan perlindungan, pengayoman, dan pelayanan kepada masyarakat.

Tindak pidana penodaan agama yang terjadi di Kota Jambi merupakan wilayah hukum Kepolisian Daerah Jambi yang memiliki karakteristik penodaan agama yang memanfaatkan penyalahgunaan ornamentornament agama yang dapat menimbulkan keresahan dan keamanan khususnya di Provinsi Jambi sebagai wilayah hukum Kepolisian Daerah Jambi maka dilakukan kebijakan-kebijakan oleh Kepolisian Daerah Jambi sebagai berikut :

1. Pembagian tugas yang lebih baik terhadap semua Polres di Polda Jambi oleh dan mengadakan kerjasama dengan Kementerian yang terkait dan Pimpinan Daerah seperti mengikuti seminar, pelatihan yang dilaksanakan dalam menambah wawasan pengetahuan tentang tindak pidana penodaaan agama sehingga dalam menjalankan tugas dapat secara efektif dan efisien dalam penyelidikan dan penyuluhan terhadap kesadaran hukum masyarakat.

2. Meningkatkan kerjasama dengan pihak - pihak terkait sebagaimana kesepakatan Forkopimda yang telah disepakati dalam menghadapi keterbatasan yang dimiliki oleh Polda Jambi tentang kepekaan dan keaktifa hal-hal yang dapat mengganggu keamanan terhadap modus-modus penodaan agama.

3. Melakukan penyelidikan dan penyidikan sampai tuntas terhadap tindak pidana penodaan agama

4. Melakukan operasi rutin dan pemantauan terhadap semua gerakan-gerakan keagamaan dalam rangka mencegah penodaan agama

\section{KESIMPULAN}

Proses penegakan hukum terhadap pelaku tindak pidana penodaan agama melalui ornamen-ornamen simbol keagamaan di ruang publik Pada Wilayah Hukum Kota Jambi diproses sesuai dengan alur Sistem Peradilan Pidana yaitu dimulai dari Sub Kepolisian yang melaksanaan proses, penyelidikan, penyidikan, dan penyerahan berkas ke pada Jaksa Penuntut umum di Kejaksaan Negeri Jambi dan mengikuti proses selanjutnya di , Kejaksaan, Pengadilan dan Pemasyarakatan. Kendala-kendala yang dihadapi dalam penegakan hukum terhadap pelaku tindak pidana penodaan agama melalui ornamen-ornamen simbol keagamaan di ruang publik pada wilayah hukum Kota Jambi adalah minimnya saksi-saksi yang mengetahui perbuatan tersebut dilakukan sehingga membutuhkan 
waktu secara berulang untuk melakukan olah TKP, pemahaman terdakwa terhadap perbuatan yang dilakukan merupakan penodaan agama, sulitnya dan membutuhkan ketelitian dalam memperoleh barang bukti, kurangnya pemahaman masyarakat. Kebijakan yang dilakukan dalam mengatasi kendala yang dihadapi oleh Kepolisian Daerah Jambi terhadap pelaku tindak pidana penodaan agama melalui ornamen-ornamen simbol keagamaan di ruang publik di wilayah hukumnya yaitu Pembagian tugas yang lebih baik terhadap penyidik Polda Jambi sesuai dengan bidang keahlian (tim pemeriksa, tim identifikasi (Inafis) serta tim IT dan pengumpulan Barang bukti) dan kedepan mengadakan kerjasama dengan Kementerian yang terkait dan Pimpinan Daerah seperti mengikuti seminar, pelatihan yang dilaksanakan dalam menambah wawasan pengetahuan tentang tindak pidana penodaaan, kerjasama dengan pihak - pihak terkait sebagaimana kesepakatan Forkopimda yang telah disepakati dalam menghadapi keterbatasan yang dimiliki oleh Polda Jambi tentang kepekaan dan keaktifa hal-hal yang dapat mengganggu keamanan terhadap modus-modus penodaan agama, Melakukan penyelidikan dan penyidikan sampai tuntas terhadap tindak pidana penodaan agama dan melakukan operasi rutin dan pemantauan terhadap semua gerakan-gerakan keagamaan dalam rangka mencegah penodaan agama

\section{DAFTAR PUSTAKA}

Anang Priyanto, "Kriminologi”, Penerbit Ombak, Yogyakarta, 2012

Abd. Moqsith Ghazali, Argumen Pluralisme Agama, Kata Kita, Jakarta, 200

Baharuddin Lopa, Permasalahan Pembinaan dan Penegakan Hukum, Jakarta, Bulan Bintang 2001,

Muladi, Beberapa Catatan Berkaitan Dengan RUU KUHP Baru, Makalah Disampaikan pada Seminar Nasional RUU

KUHP Nasional Diselenggarakan oleh Universitas Internasional Batam, Batam 17 Januari 2004

M.Ali Zaidan, , “Kebijakan Kriminal”, Sinar Grafika, Jakarta, 2016

Marzuki Wahid dan Rumadi, Fiqh Madzab Negara, Kritik Atas Politik Hukum Islam Di Indonesia, LKiS, Yogyakarta, 2001

Rusli Muhammad, Penodaan Agama Dalam Pandangan KUHP, Inti Persada, Surabaya, 2009

Sidik Sunaryo, Sistem Peradilan Pidana, Penerbit Universitas Muhammadyah Malang, 2004 